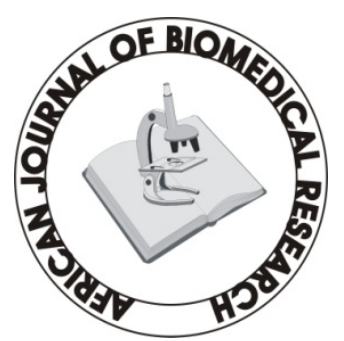

Full-text available at http://www.ajbrui.com http://www.bioline.br/md http://www.ajol.com

Received:

September 2007

Accepted (Revised): February 2008

Published

May 2008
Full Length Research Article

\section{Evaluation of the Inhibitory Potentials of Eight Higher Nigerian Fungi against Pathogenic Microorganisms}

\author{
${ }^{1 *}$ Jonathan S.G, ${ }^{2}$ Kigigha L.T and ${ }^{2}$ Ohimain E \\ ${ }^{1}$ Department of Botany and Microbiology \\ University of Ibadan, \\ Nigeria. \\ ${ }^{2}$ Department of Biological Sciences, \\ Niger Delta University, Wilberforce Island. \\ Nigeria.
}

\section{ABSTRACT}

Studies were carried out to determine antimicrobial potentials of crude and purified methanol extracts of some selected Nigerian mushrooms against some selected pathogenic microorganisms. The best in vitro antibacterial activity $(24.0 \mathrm{~mm})$ was observed with the purified extract (PRE) of Polyporus giganteus against E. coli. This was followed in order by PRE of Pleurotus florida against K. pneumoniae with $22.0 \mathrm{~mm}$ $(\mathrm{P} \leq 0.05)$. Among the screened higher fungi, only the extracts of Pleurotus tuber-regium, were able to inhibit the growth of $P$. aeruginosa. It was also observed that antifungal activities of these mushrooms were generally low. Candida albicans were inhibited by the extracts of $P$. giganteus and $T$. robustus only while other fungi produce no zone of inhibition The observed minimum inhibitory concentration (MIC) of $M$. jodocodo against E. coli was $2.75 \mathrm{mg} / \mathrm{ml}$ while that of $T$. robustus against $M$. bourlardii was $15.75 \mathrm{mg} / \mathrm{ml}$. The significance of these observations was discussed.

(Afr. J. Biomed. Res. 11:197 - 202)

Key Words; Antimicrobial, extraction, edible fungi, disease, microorganisms

*Corresponding Author: E-mail: sgjonathan@yahoo.com

Abstracted by:

African Index Medicus (WHO), CAB Abstracts, Index Copernicus, Global Health Abstracts, Asian Science Index, Index Veterinarius, Bioline International , African Journals online 


\section{INTRODUCTION}

The vegetation in the tropics supports the growth of different types of naturally occurring macrofungi Edible mushrooms are usually collected from the wild because farms growing them are very few (Zoberi, 1972; Alofe et al 1998; Gbolagade, 2007).

In many parts of Nigeria, indigenous people usually use fruit bodies and sclerotia of edible higher fungi as soup condiments which are served at their important social gatherings and family meals (Fasidi and Ekuere, 1993; Jonathan and Fasidi, 2003) Some Nigerian edible mushrooms have also been reported to possess important medicinal ingredients among the traditional doctors (Oso, 1977a and 1981; Jonathan and Fasidi, 2003 and 2005).

Mushrooms that have been implicated of having therapeutic effect against diseases such as high blood pressure, pneumonia, urinary tract infection, intestinal disorder in Nigerian etnomedical practice include Ganoderma lucidum, Fomes lignosus, Daldinia concentrica, Termitomyces species, Pleurotus species, Lycoperdon species Polyporus species, Calvatia cynthiaformis and Psathyrella atroumbonate (Oso,1977a; Jonathan,2002).

Information on in vitro antimicrobial activities of these Nigerian mushrooms is very scanty or not available in the literatures as of now. Jonathan and Fasidi (2003) reported that alcoholic extract of Lycoperdon pusilum and L. giganteum showed significant antimicrobial properties against some disease causing bacteria and fungi when compared with their respective water extracts. Likewise, Jonathan (2002) reported that antibacterial potency of puffballs could be compared with some commonly used antimicrobial agents. It is therefore the objectives of this study to describe the antimicrobial potentials of selected Nigerian edible fungi view of the limited scientific information on their medicinal values.

\section{MATERIALS AND METHODS}

Higher Fungi: Eight Higher fungi were used in this study. They include Fomes lignosus (Kl Bres),
Marasmius jodocodo (Henn), Pleurotus florida (Mont) Singer, Pleurotus tuber-regium (Fries) Singer, Psathyrella atroumbonata (Pegler), Polyporus giganteus (Fries), Termitomyces microcarpus (Berk) and Termitomyces robustus (Beeli). The sporophores of these fungi were collected from Botanical Gardens, University of Ibadan, Ibadan Nigeria. They were identified using the standard descriptions of Zoberi (1972) and that of Alexopolous et al (1996).

Preparation of methanol Extracts: The fruitbodies of collected fungal samples were air dried under shade for 5 days. They were not exposed to sun-light to prevent the ultra violent radiation from the sun from inactivating bioactive components in these fungal samples. They were oven dried at $55^{\circ} \mathrm{C}$ for $48 \mathrm{hrs}$ to a constant weight. The dried samples were milled to obtain fine powder. Eighty grammes $(80.0 \mathrm{~g})$ of the powdered sample were extracted with $320 \mathrm{ml}$ of methylalcohol in a soxhlet apparatus for 6hours. The extract was concentrated using a rotatory evaporator. The semi solid extract thus obtained was further dried into powder (Jonathan, 2002). To obtain purified extract, the solid crude extract was mixed with $1000 \mathrm{ml}$ of sterile distilled water with stirring at $4^{\circ} \mathrm{C}$ overnight. The suspension thus obtained was centrifuged to remove the insoluble matter; the aqueous supernatant was concentrated under reduced pressure to $200 \mathrm{ml}$. The concentrate was extracted with $200 \mathrm{ml}$ of ethyl acetate. This was also concentrated using rotatory evaporator to yield a light yellow material known as purified extract (Hirasawa et al, 1999). When required, both the crude and purified extracts were mixed with sterile distilled water to desired concentration.

\section{Detection of Inhibitory Activities against \\ Bacteria}

The assay for antibacterial activities in each fungal sample was determined by agar well diffusion method of stoke and Ridgway (1980). Bacteria used were $B$. cereus, E. coli, $K$. pneumoniae $P$. vulgaris, $P$. aeruginosa and $S$. aureus. The pure culture of each bacterium was inoculated to peptone water for 18 hours. These were seeded 
into nutrient agar plates (one organism per plate). Well ( $7 \mathrm{~mm}$ diameter) was made on each Petri dish using sterile cork borer. About $0.25 \mathrm{ml}$ of the extract was introduced into bore agar wells using sterile dropping pipette. The plates were kept inside the refrigerator at $4^{\circ} \mathrm{C}$ for 12 hours to allow proper diffusion of the extracts into the medium. All the experiments were carried out in triplicates. Control experiments were also set up by adding $0.25 \mathrm{ml}$ of distilled water into the well in place of the extract in three replicates. The plates were incubated at $37^{\circ} \mathrm{C}$ for 24 hours. The zones of inhibition produced were measured in milliliters (mm).

\section{Detection of Inhibitory Activities against Fungi}

The assay for antifungal potentials of these higher fungi was carried out using A. niger, A. flavus, $C$. albicans, M. boulardii and T. concentrum. Sterile plates of Saboraud dextrose agar (SDA) were prepared. Wells were made on the solid agar using $7 \mathrm{~mm}$ sterile cork borer. Twenty milligrammes $(20.0 \mathrm{mg}$ ) of the extract was mixed with $5.0 \mathrm{~g}$ of the ointment base. Two grammes $(1.5 \mathrm{~g})$ of the mixture were introduced into the well on the agar plate. The control experiment was set up with the ointment base alone (without any extract). Each experiment was replicated three times. Each Petri-dish was inoculated with test fungus and incubated at $35^{\circ} \mathrm{C}$ for 7 days. The plates were observed for any zone of inhibition which was measured in millimeters ( $\mathrm{mm}$ ).

\section{Minimum Inhibitory Concentration (MIC)}

The minimum inhibitory concentration (MIC) was aimed at finding out the lowest concentration of the extract that will inhibit the growth of the test microorganisms. Different concentrations (0.5 $20.0 \mathrm{mg} / \mathrm{ml}$ ) of the methyl alcohol extract were prepared by dissolving a known weight of the extract with a known volume of sterile distilled water. The mixture was tested against microorganisms using hole diffusion method. The test was first carried out by using high concentration of the extract $(8.0$ to $20.0 \mathrm{mg} / \mathrm{ml})$ in a completely randomized block design. Those that were still effective at $8.0 \mathrm{mg} / \mathrm{ml}$ were further diluted until no inhibitory zone was observed. The lowest concentration (dilution) at which inhibitory zone was produced is regarded as the minimum inhibitory concentration (MIC) for each extract (Pelcza et al, 1993). Each experiment was carried out in triplicates. The sterile distilled water without any fungal extract served as the control.

\section{RESULTS AND DISCUSSION}

The crude and purified extracts (CRE and PRE) of all the eight higher fungi used for this investigation possessed varying degrees of antibacterial properties against the test bacteria (Table 1). Polyporus giganteus produced the widest zone of inhibition $(24.0 \mathrm{~mm})$ against $E$. coli followed by $P$. atroumbonata $(18 \mathrm{~mm})$ against the same bacteria $(\mathrm{P} \leq 0.05)$. Fomes lignosus and $T$. microcarpus produced inhibitory zones of $16.0 \mathrm{~mm}$ each; while $M$. jodocodo possessed no antibacterial activities against $E$. coli. The strong antibacterial properties possessed by $P$. giganteus and $P$. atroubonata is not a surprise. This is because these two fungi are important part of medicinal ingredients which are used by the Yoruba people in the south western Nigeria for the treatment of intestinal disorder and some other bacterial infections (Jonathan, 2002).

All the tested extracts except $P$. giganteus, inhibited the growth of $S$. aureus. The purified extract (PRE) of both $P$. florida and $T$. microcarpus had the best in- vitro antibacterial activities (18.0mm) against this bacteria (Table 1). It was interesting to note that Pseudomonas aeruginosa which is resistant to both tetracycline and gentamycin (Jonathan, 2002; Madigan et al, 1997) was found to be sensitive to the methylalcohol extract of $P$. tuber-regium. The potent antibacterial activity exhibited by $P$. tuber-regium against most of the tested bacteria supported the earlier report of Oso (1977a and b) that P.tuberregium is a medicinal mushroom.

Klebsiella. pneumoniae was inhibited by all the extracts except $F$. lignosus and T. microcarpus (Table 1). This observation suggests that these fungi are potential antibacterial agents against infection from this organism. 
African Journal of Biomedical Research 2008 (Vol. 11) / Jonathan, Ohimain and Kigigha

Table 1:Antibacterial activities of fungal extracts

\begin{tabular}{|l|c|c|c|c|c|c|}
\hline & \multicolumn{7}{c|}{ Test Bacteria } \\
\hline Higher fungi & B.cereus & E. coli & K. pneumoniae & $\begin{array}{l}P . \\
\text { vulgaris }\end{array}$ & $\begin{array}{l}\text { P. } \\
\text { aeruginosa }\end{array}$ & S. aureus \\
\hline \multicolumn{7}{|c|}{ Inhibitory zones (mm) } \\
\hline F. lignosus (CRE) & $15.0 \mathrm{~d}$ & $13.0 \mathrm{gh}$ & - & $13.0 \mathrm{fg}$ & & $16.0 \mathrm{bc}$ \\
F. lignosus (PRE) & $17.0 \mathrm{~b}$ & $16.0 \mathrm{de}$ & - & $12.0 \mathrm{~g}$ & & $17.0 \mathrm{~b}$ \\
M. Jodocodo (CRE) & $4.0 \mathrm{j}$ & - & $10.0 \mathrm{~h}$ & $8.0 \mathrm{i}$ & & $13.0 \mathrm{ef}$ \\
M. jodocodo (PRE) & $8.0 \mathrm{i}$ & - & $13.0 \mathrm{~g}$ & $10.0 \mathrm{~h}$ & & $17.0 \mathrm{ab}$ \\
P. florida (CRE) & - & $13.0 \mathrm{gh}$ & $20.0 \mathrm{bc}$ & - & & $16.0 \mathrm{bc}$ \\
P. florida (PRE) & - & $13.0 \mathrm{gh}$ & $22.0 \mathrm{a}$ & - & $4.0 \mathrm{~b}$ & $18.0 \mathrm{a}$ \\
P. tuber-regium (CRE) & $18.0 \mathrm{a}$ & $8.0 \mathrm{j}$ & $17.0 \mathrm{de}$ & $16.0 \mathrm{~d}$ & $8.0 \mathrm{a}$ & $12.0 \mathrm{fg}$ \\
P. tuber-regium (PRE) & $18.0 \mathrm{a}$ & $11.0 \mathrm{i}$ & $19.0 \mathrm{c}$ & $18.0 \mathrm{bc}$ & & $14.0 \mathrm{de}$ \\
P. atroumbonata (CRE) & $12.0 \mathrm{~g}$ & $14.0 \mathrm{fg}$ & 10.0 & 10.0 & & $11.0 \mathrm{gh}$ \\
P. atroumbonata (PRE) & $15.0 \mathrm{~d}$ & $18.0 \mathrm{c}$ & $13.0 \mathrm{~g}$ & $14.0 \mathrm{ef}$ & & $15.0 \mathrm{~cd}$ \\
P. giganteus (CRE) & $13.0 \mathrm{f}$ & $20.0 \mathrm{~b}$ & $13.0 \mathrm{~g}$ & - & & - \\
P. giganteus (PRE) & $16.0 \mathrm{c}$ & $24.0 \mathrm{a}$ & $16.0 \mathrm{ef}$ & - & & - \\
T. microcarpus (CRE) & - & $13.0 \mathrm{gh}$ & - & $17.0 \mathrm{~cd}$ & & $16.0 \mathrm{bc}$ \\
T. microcarpus (PRE) & - & $16.0 \mathrm{de}$ & - & $20.0 \mathrm{a}$ & & $18.0 \mathrm{a}$ \\
T. robustus (CRE) & $10.0 \mathrm{~h}$ & $12.0 \mathrm{hi}$ & $13.0 \mathrm{~g}$ & - & & $6.0 \mathrm{i}$ \\
T. robustus (PRE) & $14.0 \mathrm{e}$ & $15.0 \mathrm{ef}$ & $15.0 \mathrm{ef}$ & - & & $10.0 \mathrm{~h}$ \\
Control (Distilled water) & - & - & - & - & & - \\
\hline
\end{tabular}

Key: $\mathrm{CRE}=$ Crude extract $\mathrm{PRE}=$ Purified extract

Values followed by the same letter(s) along each column are not significantly different by Duncan's multiple range test $(D M R T)(P \geq 0.05)$

Table 2: Antifungal activities of crude and purified higher fungi extracts

\begin{tabular}{|l|c|c|c|c|c|}
\hline \multicolumn{7}{|c|}{ Test Fungi } \\
\hline Higher fungi & A. niger & A. flavus & C. albicans & M. boulardii & T. concentrum \\
\hline \multicolumn{7}{|c|}{ Zone of Inhibition (mm) } & - \\
\hline F. lignosus (CRE) & - & - & - & - & - \\
F. lignosus (PRE) & - & - & - & - & - \\
M. jodocodo (CRE) & $5.0 \mathrm{e}$ & $7.0 \mathrm{e}$ & - & - & - \\
M. jodocodo (PRE) & $9.0 \mathrm{~cd}$ & $8.0 \mathrm{de}$ & - & - & - \\
P. florida (CRE) & - & - & - & - & - \\
P. florida (PRE) & - & - & - & - & - \\
P. tuber-regium (CRE) & - & - & - & - & - \\
P. tuber-regium (PRE) & - & - & - & - & - \\
P. atroumbonata (CRE) & $8.0 \mathrm{~d}$ & $10.0 \mathrm{c}$ & - & $5.0 \mathrm{c}$ & - \\
P. atroumbonata (PRE) & $10.0 \mathrm{bc}$ & $12.0 \mathrm{ab}$ & - & $8.0 \mathrm{ab}$ & - \\
P. giganteus (CRE) & $10.0 \mathrm{bc}$ & $12.0 \mathrm{ab}$ & $9.0 \mathrm{a}$ & - & - \\
P. giganteus (PRE) & $11.0 \mathrm{ab}$ & $13.0 \mathrm{a}$ & $10.0 \mathrm{a}$ & - & - \\
T. microcarpus (CRE) & - & - & - & - & - \\
T. mirocarpus (PRE) & - & - & - & - & - \\
T. robustus (CRE) & $10.0 \mathrm{bc}$ & - & $7.0 \mathrm{a}$ & $5.0 \mathrm{c}$ & - \\
T. robustus (PRE) & $12.0 \mathrm{a}$ & - & $10.0 \mathrm{a}$ & $9.0 \mathrm{a}$ & - \\
Distilled water (control) & - & - & - & - & \\
\hline
\end{tabular}

Key: $\mathrm{CRE}=$ Crude extract PRE $=$ Purified extract.

Values followed by the same letter(s) are not significantly different byDuncan's multiple range test (DMRT) (P $\geq$ $0.05)$. 
Table 3:

Minimum inhibitory concentration for bacteria and fungi.

\begin{tabular}{|c|c|c|c|c|c|c|c|c|c|}
\hline 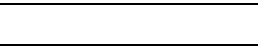 & & & Test & icrooga & sms & & & & \\
\hline Higher fungi & & & & & & & & & \\
\hline & 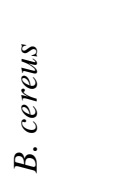 & రٓ & 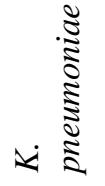 & 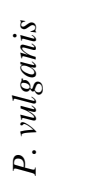 & $\begin{array}{l}\stackrel{y}{0} \\
\stackrel{\Xi}{\Xi} \\
\dot{0}\end{array}$ & 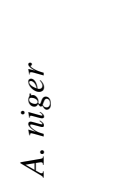 & $\frac{\sum^{a}}{d}$ & $\begin{array}{l}\tilde{E} \\
\tilde{\Xi} \\
\tilde{\Xi} \\
0 \\
ن\end{array}$ & $\begin{array}{l}\vdots \tilde{z} \\
\bar{z} \\
\frac{3}{3} \\
0 \\
\dot{s}\end{array}$ \\
\hline & & & & $(\mathrm{mg} / \mathrm{n}$ & & & & & \\
\hline F. lignosus & 5.50de & $6.00 \mathrm{bc}$ & - & $4.75 c$ & $4.50 \mathrm{e}$ & - & - & - & - \\
\hline M. jodocodo & $7.25 a$ & $2.75 \mathrm{e}$ & $6.00 \mathrm{~b}$ & $8.75 \mathrm{a}$ & 7.50a & $13.75 b$ & $15.50 \mathrm{a}$ & - & - \\
\hline P. florida & - & $7.25 \mathrm{a}$ & $7.75 \mathrm{a}$ & 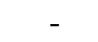 & $6.00 \mathrm{~b}$ & - & - & - & - \\
\hline P. tuber-regium & $5.00 \mathrm{e}$ & - & $6.25 b$ & $3.50 \mathrm{~d}$ & - & - & - & - & - \\
\hline P. atroumbonata & $6.50 \mathrm{~b}$ & $5.00 \mathrm{c}$ & $6.00 \mathrm{~b}$ & $4.25 \mathrm{c}$ & $4.00 \mathrm{e}$ & $14.00 \mathrm{ab}$ & $15.25 a$ & - & $13.50 \mathrm{~b}$ \\
\hline P. giganteus & $5.75 \mathrm{~cd}$ & $3.75 d$ & $3.25 \mathrm{c}$ & - & 4.75de & $10.50 \mathrm{c}$ & $12.00 \mathrm{c}$ & $13.25 a$ & - \\
\hline T. microcarpus & - & 7.00a & - & $6.00 \mathrm{~b}$ & $5.00 \mathrm{~cd}$ & - & - & - & 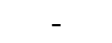 \\
\hline T. robustus & $6.00 \mathrm{bc}$ & 5.75 & $3.50 \mathrm{c}$ & - & $6.25 b$ & $14.25 \mathrm{a}$ & $14.00 \mathrm{~b}$ & $13.75 a$ & $15.75 a$ \\
\hline
\end{tabular}

Values followed by the same letter(s) are not significantly different by Duncan's multiple range test (DMRT) ( $P \leq$ 0.05).

Oso (1977a and 1981) reported that $T$. microcarpus is a powerful medicinal ingredient for the treatment of gonorrhea among the traditional doctors in the south- western Nigeria. This medicine which is administered orally is prepared by grinding a large quantity of $T$. microcarpus with the pulp of the fruit of Cucurbita pepo Linn.; the leaves of Cassia alata Linn and some other ingredients From Table 2, it was clearly revealed that the antifungal properties of the test higher fungi were generally poor. Only four of the eight screened mushroomsd exhibited weak antifungal properties on at least two pathogenic fungi. Only crude extract of $P$. giganteus showed inhibitory effect against the dematophyte (T. concentrum). Likewise, $P$. atroumbonatai and $T$. robustus inhibited the growth of $M$. boulardii. This result was similar to that reported by Jonathan and Fasidi (2003) for D. elegans and C. occidentalis. The extracts of $P$. giganteus and $T$. robustus weakly inhibited the growth of $C$. albicans while other test mushrooms exhibited no antifungal properties against this fungus. Similar inhibitory effect against $C$. albicans was observed by Jonathan (2002) for C. occidentalis and D. concentrica.

It was generally observed that purified extract (PRE) of the test macrofungi enhanced more antimicrobial activities than crude extracts (CRE).
(Tables 1 and 2). The values obtained for CRE and PRE for $M$. jodocodo against $B$. cereus were 4.0 and $8.0 \mathrm{~mm}$ respectively. Similar result was obtained for this mushroom against $A$. niger and $A$. flavus (Table 2). Eunjeon et al 1997) and Kenji et al (1993) reported similar observation with Ganoderma lucidum and Hericium erinaceum respectively. Tan and Moore (1994) Irinoda et al (1992); and Tochikura et al (1988) separately observed that purified extracts of edible mushrooms are more effective against microorganisms than crude extracts.

Table 3 shows that the minimum inhibitory concentration (MIC) of the extracts ranged between 2.75 and $15.75 \mathrm{mg} / \mathrm{ml}$. The lowest MIC $(2.75 \mathrm{mg} / \mathrm{ml})$ was found with the extract of $M$. jodocodo against E. coli. This was followed by $P$. giganteus extract against $K$. pneumoniae. Pleurotus tuber-regium and $T$. robustus had the MIC of $3.50 \mathrm{mg} / \mathrm{ml}$ each against P. vulgaris and $K$. pneumoniae respectively. Danielli (1957) suggested that the lower the MIC, the more sensitive and promising the extract. This implies that most of these higher fungi offer potential therapeutic potency against some of the medically important bacteria. The MIC against fungi was generally high. This result confirms the observation made that the higher fungi studied 
possessed poor antifungal activities.

\section{REFERENCES}

Alexopolous,C..J; Mims, C.W. and Blackwell M. (1996). Introductory Mycology $\left(4^{\text {th }}\right.$ Ed). New York John Wiley.

Alofe F.R; Odu, E.A. and Iloh, H.C. (1998). Mushrooms, man and Nature. Edible wild mushrooms on decaying wood in Obafemi Awolowo University Campus. The Nigerian Fields 63: $3-18$.

Danielli, I (1957): Antimicrobial activities of Aframomium species.Pharm.Journal of 16:470-472

Eun-Jeon P; Geonil R; Jaebae, K. and Dong H.C. (1997). Antifibrotic Effects of Polysaccharides extracts from Ganoderma lucidum. Biol. Pharm. Bull. 20 (4): $417-420$.

Fasidi,I.O and Ekuere, U.U. (1993): Studies on Pleurotus tuber-regium (Fries) Singer: Cultivation, proximate compositions and mineral contents of the sclerotia. Food Chemistry 48: 255 - 258.

Fasola,T.R ; Gbolagade, J.S. and Fasidi J.O. (2007). Nutritional requirements of Volvariella speciosa (Fr Ex. Fr) Singer, a Nigerian Edible Mushroom. Food Chemistry.100:904-908

Gbolagade,J.S ; Ajayi, A; Oku, I, and Wankasi, D (2007). Nutritive value of common wild edible mushrooms from southern Nigeria. Global Journal of Biotechnology and Biochemistry (In Press).

Hirasawa ,M; Shoujii, M; Neta T; Fukushima, K. and Takada K. (1999). Three kinds of antibacterial substances from Lentinus edodesi. (Berk) Sing. (Shitake, an edible mushroom). Int. Journ. of Antimicrobial Agents. 11:151-157.

Irinoda;,K Mashihi, N.K; Chihara G; Kaneko Y and Katori T (1992). Stimulation of microbicidal host defence mechanism against aerosol influence virus infection by Lentinan Int. J. Immunopharmal. 14 (6): 971-977.

Jonathan, S.G. (2002): Vegetative growth requirements and antimicrobial activities of some higher fungi from Nigeria. Ph.D Thesis University of Ibadan. Ibadan Nigeria.

Jonathan, S.G and Fasidi I.O. (2003). Antimicrobial activities of two Nigerian edible macrofungi Lycoperdon pusilum (Bat. Ex) and Lycoperdon gigantum (Pers). African Journal. of Biomedical Research. 6: 85 - 90.

Jonathan,S.G and Fasidi I.O. (2005). Antimicrobial activities of some selected Nigerian Mushrooms. Afr. Jour. of Biomedical Research (8): 83 - 87.

Kenji.O; Atsushis; Ryoko, S; Hideki, S; Satoshi, Y; Eumihiro O; Yukio I; Takuo, S. and Hirokazu (1993). Antimicrobial Chlorinated orcinol derivations from mycelia of Hericium erinaceum. Phytochemistry 34: (5): 1445 - 1446.

Madigan,M.T; Martinco, J.M. and Parker, J. (1997): Brock Biology of Microorganisms. (8 ${ }^{\text {th }}$ Ed.) Prentice Hall Int. Inc.

Oso ,B.A (1977b): Pleurotus tuber-regium from Nigeria. Mycologia 67 (2): 271 - 279.

Oso ,B.A (1977a): Mushrooms in Yoruba mythology and medicinal practices. Eco. Bot 31 (3): 367 - 371.

Oso,B.A (1981): Fungi and mankind. University of Ibadan, Ibadan (Nigeria) Inaugural Lecture pp 40.

Pelczar, M.J; Chan E.C.S and Krieg N.R. (1993): Microbiology: Concepts and Application. MacGrawHill Inc. New York 967 pp.

Stoke,J.E and Ridgway G.L. (1980): Clinical Bacteriology. Edward Arnold Ltd. London.

Tan,Y.H and Moore O. (1994): High concentration of mannitol in shiitake mushroom: Lentinula edodes. Microbios 79: 31 - 35 .

Tochikura,T.S ; Nakashima, H; Ohashi Y. and Yamamoto N (1988): Inhibition (in-vitro) of replication and the cytopathic effect of human immunodeficiency virus by an extract of culture medium of Lentinus edodes mycelia. Med. Microbiol. Iтти. 177:235-244.

Zoberi,M.H (1972): Tropical Macrofungi. Macmillan Press London p. 158. 